\title{
REFLECTING ON MALAYSIAN TEACHER TRAINEES' JOURNALS
}

\author{
${ }^{1}$ Aizan Yaacob, ${ }^{2}$ Lynne Masel Walters, ${ }^{3}$ Ruzlan Md Ali, \\ ${ }^{4}$ Sarimah Shaik Abdullah \& ${ }^{5}$ Timothy Walters \\ ${ }^{1,3,4}$ School of Education and Modern Languages \\ Universiti Utara Malaysia \\ ${ }^{2}$ Texas A\&M University, USA \\ ${ }^{5}$ School of Multimedia Technology and Communication \\ Universiti Utara Malaysia \\ ${ }^{1}$ Corresponding author: lynne-walters@tamu.edu
}

\begin{abstract}
"We do not learn from experience...we learn from reflecting on experience."

John Dewey
\end{abstract}

\begin{abstract}
Purpose - In this study, 37 English Language Teaching (ELT) teacher trainees from a Malaysian university conducted an action-research project to determine whether journals kept during their fieldwork in primary schools located in an area close to the university allowed them to reflect on their beliefs and behaviors in the classroom.

Methodology - Themes were revealed using emergent coding in their journals. Van Manen's (1977) three-stage model (practical, technical and critical) was used to determine the issues raised and the level of critical reflection reached in the journal entries.

Findings - The findings indicated that the teacher trainees demonstrated practical and technical level thinking, but rarely rose to the critical level of reflection. Nonetheless, they also demonstrated changes in their beliefs and behaviours, essential for professional development.
\end{abstract}

Significance - Reflective thinking is critical to teaching and is important in the United States and in countries striving to replicate its 
pedagogical tools and techniques. However, many Western practices associated with the nurturing of critical thinking are not familiar to Malaysian teacher trainees. We conclude that prospective teachers here do use their journals to reflect on their educational practice, but not at the deepest levels of insight. Critical thinking must be taught to Malaysian teacher trainees and filtered through the local culture if it is to improve teaching and learning in the nation's classrooms.

Keywords: Action research, critical thinking, Malaysia, teacher trainees, reflection, journals.

\section{INTRODUCTION}

The term "reflection" has become one of the most important vocabulary words in teacher training (Hatton \& Smith, 1995). One quality a good teacher requires is the ability to reflect on what, why and how things are done and to adapt, develop and improve his or her practices within the context of lifelong learning. Reflection is a key to successful learning for teachers.

Because of the perceived importance of reflection for educator performance, faculty in schools of education around the world are teaching and researching this practice. Many studies have shown that teacher trainees reflect at a superficial level, if at all. Collier's (1999) study of four teacher trainees found that reflective practice was typically at the lowest level of thinking (who, what, where, when of the school day), with only one trainee demonstrating an ability to reflect at the deepest level (why and how). In a study exploring the use of "scaffolded reflection" with teacher trainees, reflection was also found to remain at a superficial level (Bean \& Stevens, 2002). However, Hatton and Smith (1995) said that teacher trainees can learn the habit, despite the widespread belief that they are slow to understand and value the benefits of reflection. The development of reflective skills, then, remains a key component in most teacher education curricula today.

Reflective skills may be developed best when teacher trainees learn how to write down their thoughts, feelings, experiences and attitudes related to their work as educators. Various forms of reflective writing aids include dossiers, verbatim transcriptions, logs, diaries, 
portfolios and, more recently, digital narratives (Walters, Green, Wang, \& Walters, 2011). But it is the journal that is most often used as a vehicle for reflection.

Educators believe that reflective journals connect theory and practice. These narratives assist their creators through the articulation of emerging thoughts, encouraging a self-awareness of attitudes and beliefs over time (Collier, 1999). Reflective journals are a kind of "annotated chronological record or a 'log' of experiences and events" (Wellington 2000, 118). Not only is a document of this kind useful for providing factual information, it can also help with analysis and interpretation, in that it can jog memory and indicate patterns and trends that might have been lost if confined to the mind (Kabilan, 2007). The data collected from the reflective journals are openended, personal and generated by the participants themselves, data difficult to gather via other instruments. Yinger and Clark (1981) stress that journals provide opportunities for teacher trainees to integrate course content, self-knowledge, and practical experiences with teaching and learning.

Because of the perceived importance of reflective writing to their future practice, students at teacher colleges in Malaysia are required to keep journals throughout their practicum as indicated in the Practicum Guidebook issued by the Ministry of Education (1994). The journals are to be written in English, which has become the lingua franca of education in this multiethnic/multilingual society, although many teacher trainees are not fully proficient in this language. Teacher trainees are required to write their comments and opinions about events, problems, achievements, self or about areas of teaching that need to be given extra attention during their schoolbased experiences. Journal writing is aimed at helping teacher trainees document their reflections on their involvement at school, reevaluate the duties and responsibilities that are carried out, to use as a basis for follow-up actions and to enhance their sensitivity towards the pupils and the teacher's role. It is also meant to serve as a means for discussion with their supervisors and their cooperating teachers (Subramanian, 2012).

However, reflective journaling has been little used and less studied in Malaysia, a nation determined to rapidly improve its educators and its educational system. One of the few studies of the reflective writing 
process, as used by prospective teachers in Malaysia, was conducted at Batu Lintang Teachers' College, in Sarawak, Subramanian (2012) noted that research involving Malaysian teachers' college trainees and their perceptions is lacking. Thus, this paper attempts to do just that.

In most teacher training and preparation programs in Malaysia, reflective practice is used at both the pre-service and in-service stages of teaching (Maarof, 2007). For example, reflective journals are used during teaching practice or practicum to provide an opportunity for the teacher trainees to reflect on their training experience or journey. Kaur and Kaur (2010) reported that, in Malaysia, both the Teacher Education Department, and Education faculties, in public universities under the Ministry of Education, are required to train teachers for all public schools. They pointed out that these teacher trainees have to undergo the Practicum or Practical Teaching, a program that varies from a period of three months to six months in each institution. Interestingly, one of the objectives is to develop teachers who are reflective, as well as effective, in schools. Generally, these "teacher trainees are required to write journal entries to record their insights, reflections and critical thoughts during their teaching sessions" (Kaur \& Kaur, 2010).

Dewey (1933) maintains that reflective thinking involves two prominent components, namely the process and the content. These two components, according to Dewey, must be considered simultaneously, which this action research project does. Years later, Van Manen (1977) developed a framework for understanding the development of reflectivity. These categories serve as a benchmark for monitoring progression and growth as a teacher's level of selfefficacy (i.e. perceived belief in one's own ability to succeed at a certain task) enhances his or her reflective practices. Van Manen (1991) mentions that reflective practitioners are professionals who reflect in action, are guided by the theoretical principles of their discipline.

Models represent a schematic description of a theory, or phenomenon. Van Manen's (1977) work attempts to aid the practitioner in reflecting on past teaching events to enhance future interactions within the classroom. According to Van Manen (1977), reflective writing can be categorized at three different levels. These three levels are: 1) technical reflection, in which the focus is on the 
teacher; 2) practical reflection, in which the focus is on the student; and 3) critical reflection, in which the focus is on the context. Table 1 provides the features in reflective writing that can be classified to fall into the three different levels.

\section{Table 1}

Van Manen's (1977) Levels of Reflection

\begin{tabular}{|c|c|}
\hline $\begin{array}{l}\text { Level of } \\
\text { Reflection }\end{array}$ & Features \\
\hline Technical & $\begin{array}{l}\text { This level is concerned with the efficiency and effectiveness } \\
\text { of means to achieve certain ends, which themselves are not } \\
\text { open to criticism or modification. The reflection focuses on } \\
\text { the teacher and what works in his/her classroom; analysis at } \\
\text { this level is on the success or failure of tools and techniques } \\
\text { employed by the teacher. The experience is personal and } \\
\text { unproblematic. Valli (1990) posits that technical rationality } \\
\text { is a non-reflective level. }\end{array}$ \\
\hline
\end{tabular}

Practical A second level (Collier, 1999; Lasley, 1992; Van Manen, 1977) involves reflections regarding clarification of underlying assumptions and predispositions of classroom practice, as well as consequences of strategies used. This level allows for open examination of means and goals, the assumptions behind them, and the actual outcomes. Unlike the technical form, meanings are not absolute, but are embedded in, and negotiated through, language. Reflection focuses on students' learning experiences. Consequences of educational practices are considered, with a commitment to learning theory. The learning situation is problematic.

Critical This level includes emphases from the previous two. It also calls for considerations involving moral, social and ethical criteria (Gore \& Zeichner, 1991; Adler, 1991), making judgments about whether professional activity is equitable, just and respectful of persons or not. In addition, critical reflection locates any analysis of personal action within wider socio-historical and politico-cultural contexts (Smith \& Lovat, 1991; Noffke \& Brennan, 1988). At this level of reflection, teachers ask questions about what environmental factors support or influence their student's learning experience (Collier, 1999).

Source. Van Manen's (1977). 
The Van Manen (1977) three-stage model served as the framework for assessment of the journals that were produced as a result of this study. The teacher trainees themselves analyzed the data from their reflective writings after they completed the course "Action Research in TESL." This course was part of the Bachelor of Education program, administered jointly by the Teacher Education Division, Malaysian Ministry of Education, and the School of Education and Modern Languages, Universiti Utara Malaysia. The course aims to provide students with a practical guide to doing action research in their own classroom. As a group project, student teachers were provided the opportunity to conduct their own small-scale action research on reflective journaling, while working in nearby schools during the semester. They had to go through the procedures of conducting a research project, from gaining access into schools to teaching and doing observations and reflections. They had to complete at least two cycles of the action research (Carr \& Kemmis, 1986). At the end of the course, they were required to document their findings.

\section{METHODOLOGY}

\section{The Context}

For the purposes of this paper, the teacher trainees' journals were examined to illustrate how they viewed their readiness to become English teachers and to analyze the problems they faced during the process. Thirty-seven student teachers, each pursuing a Bachelor of Education in Teaching English to Young learners (TEYL), participated in this study. They were in their $6^{\text {th }}$ semester of study and had no teaching experience. They were given two weeks to do their fieldwork, and most chose to work in primary schools in Perlis, which is in Northern Malaysia near the University, as they could revisit the schools when the need arose.

During this experience, they worked together with the teacher and their group members to identify one particular aspect of teaching or learning that young English language learners typically have difficulties with, for example, reading or vocabulary, and arrived at solutions for the problem. Later they tried out the intended solution with the primary school students and reflected on their classroom 
experiences in journals. They were not briefed about different levels of reflection, nor were given instructions about the goals of the project or the professor's expectations, as researchers wanted the teacher trainees to define and produce their own insights on teaching. They were just told to write a reflective journal and that the purpose of the journal was to help them understand their feelings about their initial school experience. Twenty-four (64.8\%) submitted the reflective journals analyzed in this paper. The remaining students did not complete the course requirements.

\section{The Research Questions}

This study attempts to answer the following questions:

1. What do student teachers focus on when writing reflective journals?

2. What are the levels of reflection in student teachers' reflective writing?

\section{ANALYSIS OF DATA}

A total of 24 journals, written in English, were analyzed using emergent coding of themes. The first research question identifies the nature of student teachers' writing in their reflective journals. Researchers were interested in examining the focus of the writing to understand the problems the teacher trainees faced as they evolved from student learners to student teachers. The general themes that emerged in this analysis were evaluation, problem solving and consciousness.

\section{i. Evaluation}

The findings indicate that the teacher trainees evaluated their own practices in terms of successes and failures of the lesson based on whether the objectives were achieved. The analysis of their journals revealed that they were concerned about the effectiveness of their teaching tools and techniques. The experiences they wrote about were teacher-driven and personal. Teacher trainee AW realized that the students were having some difficulties in the lesson that she and her teaching cohort conducted. Through reflection, they 
evaluated their performance and improved on the action, creating a more successful second intervention. AW explained the process in her journal:

Our first intervention went well, albeit the students have some difficulties to follow the task because the task is quite hard for their level. But we managed to help them get through it and I think they did it quite well. We came back for the second intervention session with a betterprepared activity and suitable for their level. They did it brilliantly and I was in awe with their ability to complete the task (AW).

The participants also were conscious of the faults of their mentor teachers. Teacher trainee FD expressed his concern that ICT was not fully utilized in the school he visited and wondered why the teachers were still using the traditional method of chalk-and-talk instead of the new technology.

Having the opportunity to go to school enables me to have an insight view about the current situation. Based on my research on ICT, I wondered does the ICT provided by the MOE [Ministry of Education] is not fully utilized by the school. It is sad to see that the teacher does not use ICT at all! Instead (the) chalk and talk used and it makes me laugh because such method was used for centuries and it still works today (FD).

\section{ii) Problem Solving}

Another reoccurring theme was problem solving. The teacher trainees not only discussed the educational problems and issues they encountered during the process, they also thought of ways to solve these problems. This theme was more student-oriented and the reflections focused on what the class members did in the lesson and what they learned. If the lesson failed, the participants often blamed that failure on the young people in their class.

The entry about instructional technology shows that this teacher trainee was experiencing complex educational issues in which he questioned good practices in a real classroom context. He compared 
the good practices found from theories learned at the university with actual classroom teaching. Similarly, teacher trainee YT realized the problem she had in handling young learners. She felt that she had gained a new understanding of their behavior through her work at the primary school, an understanding that should help her become a better teacher.

Dealing with students is also another difficult thing to handle. Before this, I only heard that it is easy to become a teacher, but to handle them would be a big problem. Yes it's true. It was difficult to handle them especially primary school students really good at seeking attention. They expect the teacher to give attention to every action they make. Anyhow, it was a valuable experience. Maybe next time I know what I to do when I start teaching (YT).

\section{iii) Consciousness}

Another emerging theme was consciousness. Teacher trainees' journal reflections seemed to increase their awareness about their roles as teachers, even during the short school visit. They were more conscious of being career educators. They saw themselves not as individuals, but as members of a teaching profession. Undoubtedly, they became more confident and proud of their professional career. Teacher trainee FD mentioned that the experience and observations helped him to start thinking of the type of teacher he wanted to be, either an ordinary teacher with the traditional method of teaching, or a good teacher with innovative and creative teaching methods.

Such experience ...provides me with a preview of the current situation in school; it also helps me to think of what type of teacher that I'm going to be. Do I want to end up like the rest or do I opt to be a good teacher, a champion to the students with my interesting teaching. Perhaps by looking at others, I can be a better teacher (FD).

Similarly, FD realized that becoming a teacher is a difficult process. "I also got many experience from the observation part. First, I could see how becoming a teacher is not an easy job!" he wrote. 
These entries indicate that building consciousness is a cognitive process, and that, during reflection, teacher trainees thought interactively as they analyzed any problematic situation. They did not seem to separate thinking from action.

\section{Levels of Reflection}

The second research question aims to understand the level of reflection in the teacher trainees' journals. The stage of reflection in each student's journal was analyzed by the others in the action research course following Van Manen's (1977) framework. The findings indicate that more teacher trainees were at the basic technical and practical levels, although a few demonstrated a critical level of reflection. The technical level focuses upon the teacher and what works in his/her classroom, based on the analysis of the success or failure of tools and techniques employed by the teacher. The practical level demonstrates the consequences of educational practices and their commitment to learning theory.

The critical level relates the writer's personal action to the wider socio-historical and political-cultural contexts. Technical reflection, in Phipps' (2005) view, "contemplates performance based on external criteria to evaluate what changes need to occur to ensure the required improvement" (p. 62). In the practical reflection level, as pointed out by Lai and Calandra (2005), every action is seen as linked to particular value commitments. The critically reflective writer "interprets his/her individual and cultural experiences, meanings, perceptions, assumptions, prejudgments and presuppositions to better understand nature and quality of the educational experience" (p. 68).

\section{i)}

\section{Technical Reflection}

At this level, an educator considers only the technical application of educational knowledge and basic curriculum principles for the purposes of attaining a given end. The teacher is the focus at this level and the contexts of the classroom, school, community, and/or society are not seen as linked to the problem. Van Manen (1977) labels this level as the "empirical-analytical paradigm" and classifies it as the lowest level of reflection. Many student teachers in this study wrote of their success and failures of their lessons. This type of thinking 
is important for teacher trainees to understand the technical aspects of their teaching and learning, particularly the effectiveness of the techniques and tools used in the classroom. Lai and Calandra (2007) assert that "technical reflection, is concerned with the application of educational knowledge to attain ends accepted as given [and] neither the ends nor the educational contexts are treated as problematic" (p. 68).

Teacher trainee DV explained that it was difficult to solve students' problems successfully, which required her to be patient and meticulous in the planning process.

This research project is an eye opener to me. To think of a student's problem and coming up with a method to overcome it and then see if our method is successful or not, is a very tough job. It needed a lot of patience and we had to be very meticulous in planning our work. (DV).

DW on the other hand, explained that teachers should create good relationships in the classroom, and that this, in turn, would bring about positive reactions from her students.

Since I love working with children, I truly enjoyed myself conducting the research with my group members. I became quite attached with the children and they seemed to like me too. They were very enthusiastic and active when we conducted the sessions with them. From my experience, I learned that in order to be a successful teacher, we must understand the young souls (DW).

\section{ii) Practical Reflection}

In the practical reflection stage, the focus was on the students, goals and actual outcomes, not merely on the teacher's tools and techniques. Practical reflection also indicates one's ability to link theory with practice. As teacher trainees become more student-driven, they are concerned about what students are learning. In practical reflection, the goals and means are questioned, and meaning is not absolute but constructed through language. Usher, Tollefson, and Francis (2001) 
note that "the practical (or theoretical) level where it is realized that any choice requires a process of analyzing and clarifying individual and cultural experiences, meanings, perceptions, assumptions and prejudgments" (p.16).

Student HZ mentioned that the experience made him conscious of the real situation and helped him to improve himself. In a similar vein, Student K reflected on his own teaching and became aware of what he should and shouldn't do as a teacher.

\begin{abstract}
I believe the research is a good start for us to learn the actual situation in classroom and we are given the insight of the idea to be able to reflect and later to improve ourselves (HZ).
\end{abstract}

This research has given me a priceless experience and I personally think that it will help me a lot by the time I become a teacher in the near future. The time that I have spent with the children has given me opportunity to reflect on my own teaching practice, things that I should do and things that I should avoid when I become a teacher $(\mathrm{K})$.

Student L felt that students' learning should be given careful attention and that learning should be fun and teachers should come up with modern teaching techniques.

I have learnt a lot from action research and I think it is a subject, which should not be overlooked because teacher-trainees can come up with useful contemporary teaching activities, which can help students, learn and at the same time have fun (L).

On the other hand, S indicated her awareness of using the Multiple Intelligences Theory in her lesson. She demonstrated the practicality of using the theory, while introducing new methods of teaching vocabulary through fun activities.

I personally feel our research with the title 'enhancing vocabulary through language games' was a success as 
we reached our objectives. We managed to use Howard Gardner's Multiple Intelligences to teach them, like asking them to draw. We also managed to teach them new vocabulary like variety, energy and also how to construct sentences based on the vocabulary. Students had fun and they did learn new things. The evidence can be seen in students' interview conducted at the end of the research. Language games made it easier to learn new vocabulary instead of chalk and talk or merely the traditional way ...students learn English best in a fun way (S).

Similarly, P demonstrated the effectiveness of collaborative learning in helping students to share ideas and to foster teamwork.

I feel our research was a success because we could measure the students' improvement on reflecting our objective that has been reached. I also believe that collaborative learning do help students to learn better because they can share their ideas and help each other to do well in the task given $(\mathrm{P})$.

\section{iii) Critical Reflection}

Critical reflection is a cognitive activity during which one carefully considers the impact of one's actions upon others, and provides a rationale, taking into account the social, cultural and/or political forces at work in the event (Hatton \& Smith, 1995). It also involves moral and ethical judgment of one's action. Critical reflection is situated within socio-historical contexts. Educators are concerned with knowledge and the social circumstances useful to students, without distortions of personal bias. Reflective questions students can ask themselves in this stage of critical analysis are:

- What were essential strengths of the lesson? What were the weaknesses?

- What moral or ethical values were embedded in this lesson?

- What, if anything, would I change about the lesson? Could I have taught the material in any other way?

- Which conditions were important to the outcome? 
- What, if any, unanticipated learning outcomes resulted from the lesson?

- Was the content covered important to students? Why? Why not?

Given the fact that another reflection study in Malaysia had no entries in this category (Subramanian, 2012), it was not a surprise that only a few teacher trainees participating in this project demonstrated a evel of critical lreflection. F noted:

My school experience during AR has been a terrific one. I learned a lot of things especially regarding teaching. As a teacher we not only have to teach and try to finish the syllabus.... Instead we should make sure that students are able to use what they have been taught in class into the real world (F).

F's entry demonstrates awareness of the students' rights to apply the school knowledge to the real world. He makes judgments within his wider socio-cultural contexts. This explains what is proposed by Van Manen in his level of critical reflection.

\section{$\mathrm{Z}$ demonstrated increased awareness of his responsibility to help the poor students.}

For this semester, we have to do action research at a school nearby. At first, we felt very demotivated to go to school as in this semester there are many things need to be done. As we have conducted the research for about six times, the feelings have gradually changed. I find out that this is my responsibility to help the poor students. I want to be a good English teacher... (Z).

He also indicated that having a "true heart" is important in creating good citizens in a great nation. "I can't wait to become a teacher," Z concluded. Z's entry demonstrates that he is locating his analysis within a wider socio-historical context (Smith \& Lovat, 1991) by thinking about creating good citizens among his students in order to build a great nation.

In sum, while most students fell in the technical and practical levels of reflection in their journal entries, there were a few students who 
reached the critical level, whereby they managed to situate their experiences within socio-cultural contexts.

\section{RESULTS AND DISCUSSION}

In this paper we have attempted to show the nature of teacher trainees' reflective writings in an action research project conducted in northern Malaysia. Our findings revealed that the participants evaluated their practices by focusing on teaching and learning problems and the effective methods of managing the classroom and delivering the lessons. They also demonstrated an increased consciousness of the teaching and learning situations in their journals. The general themes found in earlier studies, suggesting that teacher trainees' reflective practices will bring about evaluation, problem solving and consciousness (Isoglu, 2007; Kemmis \& McTaggart, 1988).

Action research allows prospective teachers to see their own behavior, monitor their practice and outcomes. It also enables them to increase their consciousness of their values, attitudes and beliefs about teaching and learning. This study supports the "teacherresearcher" concept. Carr and Kemmis (1986) proposed that action research involves "improvement of practice, improvement of understanding of practice, and improvement of situation in which practice takes place." Most importantly, action research empowers the creator's ownership and control of the research (McGee, 2008). In relation to the levels of reflection, our findings indicate that the vast majority of teacher trainees were in the technical and practical levels. These findings resonate with most previous studies. (See for example, Isoglu, 2007; Francis, 1995; and Subramanian, 2012). Our teacher trainees wrote of the success and failures of their lessons, their disappointments and self-doubts (Hoover, 1994). They were concerned about the effectiveness of the teaching method to achieve certain ends.

Additionally, what we have discovered here is that action research helped teacher trainees in their professional development by making them doubly reflective about their teaching. First, they used their journals to consider the educational environment and their role in it. Second, they used the action research project to reflect on the 
meaning of their journal entries. The teacher as researcher concept has increased student teachers' awareness of the complex educational issues and understanding of young learners' problems.

\section{CONCLUSION}

This study was merely a small-scale exploratory action-research project in one course. The intention of such research is not to generalize, but to raise issues that may be relevant to other such projects and may apply to student teachers in different contexts.

Clearly, a reflective journal provides an avenue in maximizing ELT potential among teacher trainees, provided that they were taught to reach a higher level of reflection to fully benefit from their experiences. In this study, the student teachers were not informed or taught of the different levels of reflection. They showed the ability to use suitable teaching methods or techniques to achieve teaching and learning objectives. They managed to develop and describe their own assumptions and beliefs, to analyze and make judgments about the choices that they made in their teaching efforts, but did not take into consideration moral and ethical outcomes of their teaching action. The trainees did not think through the consequences of their teaching actions to human needs, justice and equality. This is not their fault. Teacher trainees need proper scaffolding to reach a higher level of reflection. This is important because reflection is not as common a practice among Malaysian educators, as it is with their Western counterparts. Moreover, they wrote their journals in English, a second or third language, and may not have had the vocabulary to express their personal emotions and critical thoughts.

As teacher educators in an Asian nation, we have to promote not only reflective thinking among our students, we also must make them see reflection as a useful activity. Boyd, Boll, Brawner, and Villaume (1998, p.70) suggest that we can "promote growth as reflective professionals by assisting our students in questioning as a way of learning, in developing a coherent philosophy, and in committing to ongoing professional inquiry."

This study suggests that we can promote reflective writing activity as a powerful approach for prospective teachers' professional 
development. We also need to explore whether cultural factors, such as the habit of writing or keeping journals or diaries, influences the "end product" of their writing and the "detection" of reflection by the researcher. The impact of proficiency in a second or third language (as English was for many participants) on critical thinking and journal writing for reflection is also another area for further research (Subramanian, 2012).

In line with the activities of reflection, in-service and pre-service teachers are encouraged to be involved in classroom, or action, research. This type of research attempts to improve and also understand practices through direct teachers' involvement and action. Carr and Kemmis (1986) assert that the 'teacher-asresearcher' concept would provide a means of teachers becoming critical. In their view, "action-research involves the improvement of practice, the improvement of the understanding of the practice by the practitioners, and the improvement of the situation in which practice takes place" (Carr \& Kemmis 1986). In sum, it is another form of reflection on a teacher's beliefs, values, behaviors and skills. Studies have also documented the success of critical reflection for teachers' professional development (McGee, 2008; Kennedy, 1993). McGee (2008) describes the success of reflection during an action research project and discovers the significant role of action research in encouraging reflection in a collaborative environment, promoting a culture of learning and supporting the participant's reconstruction of professional knowledge. Her study also highlights the ownership and control of the research by an action researcher.

Collier (1999) commented on the critical level, indicating that student teacher education should aim for this level, even though it is difficult to reach. Most student- teachers exhibit technical rather than critical reflective skills. "Many researchers," wrote Risko et al., "concluded that developing deep levels of reflection is difficult for prospective teachers and generated few clues as to why this may be so and what can be done to better support their reflective development" (Risko, Vukelich \& Roskos, 2002). Similarly Isikoglu (2007), in her study of early childhood pre-service teachers' reflective writings, discovered that student teachers reflected at routine and technical levels, rather than at the critical level. She commented that student teachers were in the process of professional development and change. Their 
personal and teaching experiences, culture, and the school system in which they are participating influenced this process.

As individuals, teachers come with preconceived notions about the learning process, the students themselves, and the education program in general. Educators cannot separate themselves as social beings from their beliefs, since constructions occur within varying sociocultural contexts (Flores, 2001). Attitudes are important because they affect teachers' motivation to engage with their students, which can, in turn, translate into higher student motivation and performance (Karabenick \& Noda, 2004).

Attitudes and motivation are major issues in Malaysia. Student teachers have limited experience in writing journals and reflecting on their teaching. Moreover, they have to write a journal in English in a non-native English-speaking environment. Critical thinking is crucial in terms of learning for an unknown future. Indeed a case could be made that it is THE fundamental educational ideal (Bailin \& Seigal, 2003). For students, especially those with limited English, the specter of critical thinking is usually their greatest fear. A working knowledge of English is not enough for critical thinking, in the Western sense. The skill must be taught to Asian students if to succeed in a Western-influenced educational environment.

Research suggests that repeated exposure to reflection, however, does not guarantee that teacher trainees will develop critical or higher levels of reflective thinking (Bean \& Stevens, 2002). Growing evidence suggests that novice teachers are still struggling to make the psychological shift required when moving into their roles as educators. In their preoccupation with the process of teaching, the process of learning is frequently overlooked (Collier, 1991). This may be especially true in Malaysia. Reflection is a key component of many teacher development models, and the skills of self-inquiry and critical thinking are seen as central for continued professional growth. As we share these educational viewpoints, in which reflection is an essential characteristic of teaching and learning, we believe that English teachers in Malaysia must be convinced of its worth. 


\section{REFERENCES}

Adler, S. (1991). The reflective practitioner and the curriculum of teacher education. Journal of Education for Teaching, 17(2), 139-150.

Bailin, S. W., \& Siegel, H. (2003). Critical thinking. In Blake, H., Smeyers, P., Smith, R. \& Standish, P. (Eds.), The Blackwell Guide to the Philosophy of Education (pp. 181-193). Malden, Massachusetts: Blackwell.

Bean, T. \& Stevens, L. (2002). Scaffolding reflection for preservice and inservice teachers. Reflective Practice, 3(2), 205-218.

Boyd, P.C., Boll, M., Brawner, L., \& Villaume, S.K. (1998). Becoming reflective professionals: An exploration of preservice teacher's struggles as they translate language and literacy into practice. Action in Teacher Education, XIX(4), $61-75$.

Carr, W., \& Kemmis, S. (1986). Becoming critical. London: Falmer Press.

Collier, S. (1999). Characteristics of reflective thought during the student teaching experience. Journal of Teacher Education, 50(3), 173-181.

Dewey, J. (1933). How we think: A restatement of the relation of reflective thinking to the educative process. Boston: Houghton Mifflin. Educational Review, 57, 23-48.

Flores, B. (2001). Bilingual education teachers' beliefs and their relation to self-reported practices. Bilingual Research Journal, 25(3), 251-275.

Francis, D. (1995). The reflective journal: A window to preservice teachers' practical knowledge. Teaching \& Teacher Education, 11(3), 229-241.

Gore, J., \& Zeichner, K. (1991). Action research and reflective teaching in preservice teacher education: A case study from the United States. Teaching and teacher education, 7(2), 119-136.

Hatton, N., \& Smith, D. (1995). Reflection in teacher education: Towards definition and implementation. Teaching \& Teacher Education, 11, 33-49.

Hoover, L. (1994). Reflective writing as a window on preservice teachers' thought process. Teaching \& Teacher Education, 10(1), 83-93. 
Isikoglu, N. (2007). The role of reflective journals in early childhood pre-service teachers professional development. Educational Sciences: Theory \& Practice, 7(2), 819-825.

Kabilan, M.K. (2007). English language teachers reflecting on reflections: A Malaysian experience. TESOL Quarterly, 41(4), 681-705.

Kaur Sidhu, G., \& Kaur, S. (2010). Pathways to reflective learning and teacher development: Insights from teacher trainees' diaries. Jurnal Pendidikan Malaysia, 35(1), 47-57.

Kemmis, S., \& McTaggart, R. (1988). The action research planner. Melbourne, Australia: Deakin University.

Kennedy, J. (1993). Meeting the needs of teacher trainees on teaching practice. ELT Journal, 47(2), 157-165.

Karabenick, S., \& Noda, P. (2004). Professional development implication of teachers' beliefs and attitudes toward English language learners. Bilingual Research Journal, 28(1), 55-61.

Lasley, T. (1992). Promoting Teacher Reflection. Journal of Staff Development, 13, 24-29.

Lai, G., \& Calandra, B. (2007). Using online scaffolds to enhance preservice teachers' reflective journal writing: A qualitative analysis. International Journal of Technology in Teaching and Learning, 3(3), 66-81.

Maarof, N. (2007). Telling his or her story through reflective journals. International Education Journal, 2007, 8(1), 205-220.

McGee, A. (2008). Critical Reflections of action research used for professional development in a Middle Eastern Gulf State. Educational Action Research, 16(2), 253-250

Ministry of Education. (1994). Practicum I guidebook for fivesemester teacher training programme at teacher colleges in Malaysia. Kuala Lumpur: Ministry of Education.

Noffka, S., \& Brennan, M. (1988, April). The dimensions of reflections, A conceptual and contextual analysis. Paper presented at the annual meeting of the AERAA, New Orleans, Louisiana.

Phipps, J. J. (2005). E-Journaling: Achieving interactive education online. Educause Quarterly (1), 62-65.

Risko, V., Vukelich, C., \& Roskos, K. (2002). Preparing teachers for reflective practice: Intentions, contradictions, and possibilities. Language Arts, 80(2), 134-144. 
Smith, D., \& Lovat, T. (1991). Curriculum: Action on reflection (2nd ed.). Wentworth Falls, New South Wales: Social Science Press.

Subramanian, M. (2012). Journal writing as a tool for teacher trainees: Reflection on teaching. Retrieved from http://www. ipbl.edu.my.

Usher, K., Tollefson, J., \& Francis, D. (2001). Moving from technical to critical reflection on journaling: An investigation of students' ability to incorporate three levels of reflective writing. Australian Journal of Advanced Nursing, 19(1), 15-19.

Valli, L. (1990). Moral imperatives in reflective teacher education programs. In R.T. Clift,

W.R. Houston, \& M. Pugach (Eds.)' Encouraging reflective practice: An examination of issues and exemplars (pp. 3956). New York: Teachers College Press.

Van Manen, M. (1977). Linking ways of knowing with ways of being practical. Curriculum Inquiry, 6, 205-228.

Van Manen, M. (1991). Reflectivity and the pedagogical moment: The normativity of pedagogical thinking and acting. Journal of Curriculum Studies, 23, 507-53.

Walters, L., Green, M., Wang, L., \& Walters T. (2011). From heads to hearts: Digital stories as reflection artifacts of teachers' international experience. Issues in Teacher Education, 20 (2), $37-52$.

Wellington, J. (2000). Educational research: Contemporary issues and practical approaches. New York, New York: Continuum.

Yinger, R. \& Clark, C. (1981). Reflective journal writing: Theory and practice. Institute for Research on Teaching. East Lansing, Michigan: Michigan State University. 